\title{
An Essential Yeast Gene with Homology to the Exonuclease- Encoding XRN1/KEM1 Gene Also Encodes a Protein with Exoribonuclease Activity
}

\author{
MARGARET KENNA, ${ }^{1} \dagger$ AUDREY STEVENS, ${ }^{2}$ MARK MCCAMMON,${ }^{3}$ AND MICHAEL G. DOUGLAS ${ }^{1 *}$ \\ Department of Biochemistry and Biophysics, University of North Carolina Medical School, University of \\ North Carolina at Chapel Hill, Chapel Hill, North Carolina 27599-72601; Biology Division, \\ Oak Ridge National Laboratory, Oak Ridge, Tennessee 37831-8077² and Department \\ of Biochemistry, Southwestern Graduate School of Biomedical Sciences, \\ University of Texas Health Science Center, Dallas, Texas $75235^{3}$
}

Received 2 July 1992/Returned for modification 18 August 1992/Accepted 12 October 1992

\begin{abstract}
An essential gene, designated HKE1/RAT1, has been isolated from the yeast Saccharomyces cerevisiae and characterized. The gene encodes a protein of $116 \mathrm{kDa}$ (p116) and has significant homology to another yeast gene $(X R N 1 / K E M 1)$ encoding a related protein (p175) with $5^{\prime} \rightarrow 3^{\prime}$ exonuclease activity as well as activities involving chromosomal DNA pairing and mechanics. Preliminary analysis of an $h k e 1^{\text {ts }}$ mutant reveals a precipitous decline in the translation of mRNA at the nonpermissive temperature. Sporulation of heterozygous HKE1/hke1::URA3 diploids reveals that this gene, unlike the highly related $X R N 1 / K E M I$ gene, is essential for cell viability. Overexpression of the homologous gene product, p175, failed to rescue cells lacking a functional p116. In vitro studies demonstrate that p116 is a protein with $5^{\prime} \rightarrow 3^{\prime}$ exoribonuclease activity, a major activity of the related p175. An immunoreactive RNase activity of $116 \mathrm{kDa}$ is abolished with antiserum against p116. Both the level of this protein and the RNase activity correlate with $H K E 1$ gene dosage. The RNase activity purifies coincidentally with a previously described 116-kDa RNase having $5^{\prime} \rightarrow 3^{\prime}$ exoribonuclease activity.
\end{abstract}

We have characterized a temperature-sensitive $(t s)$ mutant from Saccharomyces cerevisiae that was obtained in a screen for mutants reduced in the synthesis or binding of a hybrid protein which competes for the transport of protein precursors into mitochondria (8). Analysis of this mutant has led to the characterization of a gene with significant primary sequence homology to a previously identified gene, XRN1 (25). $X R N 1$ was also independently identified as $K E M 1$ (18), $S E P 1$ (42), DST2 (10), and RAR5 (19). The gene is referred to as $X R N 1 / K E M 1$ in this paper. It encodes a protein of 175 $\mathrm{kDa}(\mathrm{p} 175)$ which appears to have a multitude of properties, including involvement in such seemingly diverse functions as recombination, RNA processing and turnover, microtubule function, karyogamy, and DNA replication (for a summary, see reference 17). The protein has $5^{\prime} \rightarrow 3^{\prime}$ exoribonuclease and DNase activity as well as DNA strand-exchange activity $(10,25,42)$. XRN1/KEM1 gene disruptions have shown that it is a nonessential gene. The related gene described in this report was originally designated $H K E 1$ (for homology to $K E M 1$ ). Yeast cells lacking functional $H K E 1$ are not viable and cannot be rescued by $X R N 1 / K E M 1$, even in high copy. Analysis of the hkel temperature-sensitive mutant shows a reduction in the translation of RNA at the nonpermissive temperature. Furthermore, p116 appears to have $5^{\prime} \rightarrow 3^{\prime}$ exoribonuclease activity, as does the related p175 protein. The nuclear immunolocalization of p116 suggests that its participation in the utilization of mRNA may occur prior to the translation of mRNA in the cytoplasm. These phenotypes associated with $h k e 1-1^{t s}$ may indicate a role for this protein in the processing and/or trafficking of nuclear mRNAs.

\footnotetext{
* Corresponding author.

$\dagger$ Present address: Howard Hughes Medical Institute, Duke University Medical Center, Durham, NC 27713.
}

In order to understand the activities which operate to ensure correct processing and transport of RNA, at least two studies have been initiated with yeasts to take advantage of the genetic approaches available $(3,16)$. One of these studies, designed to uncover RNA trafficking mutants in Saccharomyces cerevisiae, has yielded a temperature-sensitive mutant that is complemented by a gene identical to $H K E 1$ (named $R A T 1$ for RNA trafficking [3]). In this study, poly(A) RNA localization methods were used to screen for conditional mutants which appear to be blocked in the transport of RNA molecules from the nucleus at the restrictive temperature. Mutants obtained from these screens (3, 16) appear to be distinct from previously described mutants that exhibit defects in cytoplasmic mRNA production due to mRNA splicing (26; for a review, see reference 32 ).

The studies presented here describe further characterization of the $H K E 1 / R A T 1$ gene and an $h k e 1^{t s}$ mutant and show that p116 is a protein having $5^{\prime} \rightarrow 3^{\prime}$ exoribonuclease activity, a major activity of the product of the related $X R N 1 / K E M 1$ gene.

\section{MATERIALS AND METHODS}

Strains and media. The following yeast strains were used in this study: SEY2101 (MATa ura3-52 leu2-3,112 suc2- $\Delta 9$ ade2-1 gal2); SEY2102 (MAT $\alpha$ ura3-52 leu2-3,112 suc2- $\Delta 9$

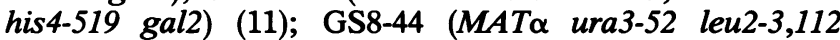

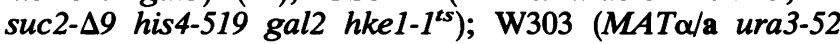
leu2-3,112 his3-11,15 trp1-1 ade2-1); YPH500 (MATa ura3-52 lys2-801 ade2-101 trp1- $\Delta 63$ his3- $\Delta 200$ leu- $\Delta 1$ ); and

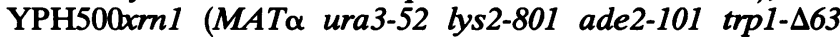

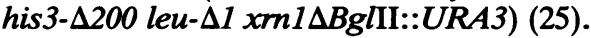

Yeast cells were grown in YPD rich medium (1\% yeast extract, $2 \%$ peptone, and $2 \%$ glucose) or minimal medium (YNBD [0.67\% yeast nitrogen base, $2 \%$ glucose] or YNBG 
[ $0.67 \%$ yeast nitrogen base, $2 \%$ glycerol]) supplemented with appropriate amino acids (34). LSM was used for labeling experiments (8).

The Escherichia coli strain used for plasmid construction

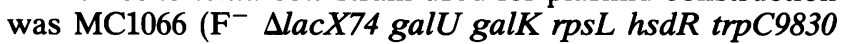
leuB600 pyrF74::Tn5) (29). Bacteria were grown in LB medium (30). Ampicillin-resistant transformants were selected on LB plates supplemented with $50 \mu \mathrm{g}$ of ampicillin per ml (30).

Plasmids. The plasmid, pMKHKE1, is the $2 \mu \mathrm{m} L E U 2$ YEp13-based plasmid containing a 5.1-kb insert, including the entire $H K E 1 / R A T 1$ gene, in the BamHI site (see below). The plasmid pExo2, a YEp24-based plasmid from Larimer and Stevens (25), contains the $X R N 1$ gene. An $\sim 8-\mathrm{kb}$ BamHI-HindIII fragment containing the entire $X R N 1$ gene was subcloned into YEp13 to create YEp13XRN1.

Isolation of the temperature-sensitive mutant. The original temperature-sensitive strain GS8-44 (hke1-1) was identified as a $t s$ mutant from a screen in yeast cells designed to detect the mislocalization of a fusion protein in vivo. Earlier studies had demonstrated that mitochondrial association of an ATP2-lacZ-encoded hybrid protein to the mitochondrial inner membrane prevents growth on nonfermentable carbon sources by an otherwise wild-type host $(8,11)$. A genetic screen was devised to select conditional mutants that would suppress the no-growth phenotype of this hybrid protein yet still harbor the plasmid, as assayed for by growth on glycerol and $\beta$-galactosidase activity.

Mutagenesis and genetic analysis. Strains SEY2101 and SEY2102, both carrying plasmid pCBZ1 (the ATP2-lacZ plasmid [8]), were mutagenized with either ethyl methane sulfonate (34) or UV irradiation. For UV mutagenesis, cells were treated at a cell density of $10^{7} / \mathrm{ml}$ in $\mathrm{H}_{2} \mathrm{O}$ to give approximately $40 \%$ killing. After mutagenesis, cells were plated onto YNBG plus 5-bromo-4-chloro-3-indolyl- $\beta$-D-galactopyranoside with amino acid supplements and $0.1 \%$ glucose. Colonies growing on these plates after 7 to 10 days at room temperature which expressed observable $\beta$-galactosidase activity (30) were selected for further study (approximately $10^{-3}$ of survivors). Candidates were subjected to multiple rounds of screening and were checked for temperature-sensitive growth at 30 and $37^{\circ} \mathrm{C}$ on both glucose- and glycerol-containing media. This screening eliminated approximately $85 \%$ of the candidates. To confirm that the lesion was chromosome linked, the original pC $\beta Z 1$ was segregated out by screening for uracil prototrophy and loss of $\beta$-galactosidase expression. Strains were retransformed with fresh pCBZ1 and screened for growth on YNBG. Approximately $60 \%$ of the final-found candidates lost the ability to grow on YNBG upon retransformation with pC $\beta Z 1$.

Complementation analysis between SEY2101- and SEY2102-derived mutants and backcrosses followed standard genetic protocols (34), as did tetrad analysis and random spore analysis to select haploids by using the ade2-1 allele. GS8-44 (hke1-1 $\left.{ }^{t s}\right)$ was the strain chosen for the genetic and molecular analyses described in this report. Other mutants will be described elsewhere.

Cloning the HKE1/RAT1 gene. Strain GS8-44 (hke1-1 $\left.{ }^{\text {ts }}\right)$ was transformed with a yeast Sau3A genomic library inserted into YEp13. Cells were plated on media selective for transformants at room temperature for 1 day before shifting to $37^{\circ} \mathrm{C}$. After 2 days at $37^{\circ} \mathrm{C}$, fast-growing colonies were isolated and rescreened for their ability to complement hke1-1. Four independent plasmids were identified from over $19,000 \mathrm{Leu}^{+}$transformants. The insert DNA from each of the plasmids shared a common region of $4.1 \mathrm{~kb}$ which contained the full-length gene.

Complementation by $\mathrm{HKE1}$ on a centromere plasmid. A 5.1-kb fragment bearing the $H K E 1$ gene and $5^{\prime}$ and $3^{\prime}$ flanking DNA was amplified by polymerase chain reaction (PCR) with primers flanking the BamHI site of YEp13 in the plasmid pMKHKE1. This insert was then cloned into the BamHI site of pRS316, a CEN6 plasmid (35), and transformed into GS8-44 and its derivatives. The ability of the gene to complement the $t s$ mutation was analyzed by growing cells containing this plasmid at 23 and $37^{\circ} \mathrm{C}$.

Integrative mapping. Integrative mapping was used to demonstrate that the gene cloned by complementation of the ts mutant mapped to the same genetic location as the allele responsible for the temperature-sensitive phenotype. A 2.3-kb SalI fragment from YEp44-7, one of the four complementing plasmids, was subcloned into the yeast integrating vector YIp5. Integration of this plasmid was directed to the $H K E 1$ region of the genome by transforming wild-type strain SEY2101 with KpnI-linearized DNA. Correct integration at the $H K E 1$ locus was confirmed by Southern analysis of genomic DNA prepared from the transformant. This transformed strain was then mated to GS8-44 containing the temperature-sensitive hke 1-1 mutation. Diploids were sporulated, and the $\mathrm{Ura}^{+}$phenotype was meiotically mapped in relation to the hke1-1 allele. Tetrad analysis confirmed that the cloned sequence represents the wild-type gene of the mutant allele in the hke1-1 strain.

Yeast transformation. Yeast cells were made competent for transformation with lithium acetate (14).

Nucleic acid methods. Standard procedures were used for restriction digestions and plasmid constructions. Restriction enzymes and T4 DNA ligase were used according to the instructions of the supplier. DNA fragments were purified from agarose, and DNA transformation in $E$. coli was performed as described by Maniatis et al. (27).

The $H K E 1$ gene was sequenced as either a single-stranded or double-stranded template. Dideoxy sequencing of DNA was accomplished by using a kit from New England Biolabs, single-stranded DNA cloning vectors, and universal primers. Double-stranded plasmid DNA was sequenced with either Sequenase (United States Biochemical Corp.) or a doublestranded DNA cycling sequencing system (Bethesda Research Laboratories) using Taq DNA polymerase. The sequencing vector Bluescript (Stratagene) was used to subclone certain restriction fragments of $H K E 1$, and sequence was obtained from universal sequencing primers. Oligonucleotides were synthesized and used as primers to complete some regions. DNA data analysis was performed by using the MacVector (IBI) program. Protein sequence alignment with sequences in the NBRF and GenBank data bases was performed by using the TFASTA program within the University of Wisconsin Genetics Computer Group program (7). The DNA sequence and protein sequence alignment were identical to those previously presented (3).

Disruption of $H K E 1$. A 5.1-kb fragment bearing the $H K E 1$ gene and $5^{\prime}$ and 3 ' flanking DNA was amplified by PCR with primers flanking the BamHI site of YEp13, in the plasmid pMKHKE1. Additional BamHI sites were created de novo by the PCR method and used for convenient subcloning of the entire genomic fragment containing $H K E 1$ as a single $B a m \mathrm{HI}$ fragment. The 5.1-kb Bam HI fragment was cloned into the BglII site in the polylinker region of pSP71 (Promega) to create pHKE71. pHKE71 was digested with SalI-SacII to remove a $430-$ bp internal fragment near the $5^{\prime}$ 


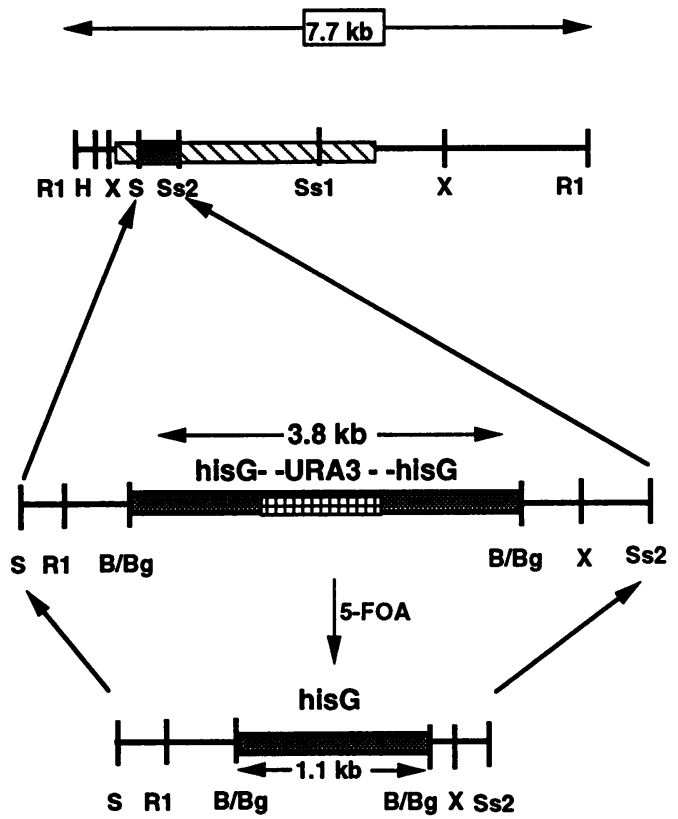

FIG. 1. HKE1/RAT1 is an essential gene. DNA constructions to disrupt $H K E 1 / R A T 1$. A 3.8-kb that consists of the yeast $U R A 3$ gene flanked by direct repeats of Salmonella hisG DNA (2) was used to disrupt HKE1/RATI by insertion into the Sall-SacII sites within the $5^{\prime}$ region of the gene (restriction sites used were as follows: $\mathrm{B} / \mathrm{Bg}$, BamHI-BglII; H, HindIII; R1, EcoRI; S, SalI; Ss1, SacI; Ss2, SacII; and X, XbaI) as described in detail in Materials and Methods. A linear fragment containing this construct was then used to transform the diploid strain W303. Tetrad analysis of the HKE1/ hke1::URA3 diploid revealed a segregation pattern of 2 viable spores: 2 inviable spores. Treatment of $\mathrm{Ura}^{+}$transformants with 5-FOA selects for cells that have excised the URA3 gene because of recombination between the direct repeats of the his $G$ gene and are therefore ura 3 mutants but maintain the hke1::his $G$ gene disruption. Tetrad analysis of this diploid also gave rise to 2 live: 2 dead spores.

end of $H K E 1$. The linear $\sim 7-\mathrm{kb}$ fragment was isolated and used as the recipient for the input DNA described below.

A 3.8-kb fragment that consists of the yeast URA3 gene flanked by direct repeats of Salmonella hisG DNA (2) was subcloned into the polylinker region of Bluescript vector (Stratagene). A SalI-SacII fragment was isolated from this construct and subcloned into the SalI-SacII site within the $H K E 1$ gene in pHKE71. The resulting plasmid, pHKE71:: hisGURA3, was digested with XhoI and AatII to release an $\sim 8$-kb fragment useful for integrative transformation into the diploid yeast strain W303 (31). Ura ${ }^{+}$transformants were selected and confirmed by Southern analysis. Individual transformants were subsequently used to detect excision events that would lead to a $\mathrm{Ura}^{-}$phenotype and were selected for on 5-fluoro-orotic acid (5-FOA) (5). Figure 1 depicts the disrupted $H K E 1$ gene.

Antibody production. An in-frame gene fusion between the $E$. coli trpE gene and $H K E 1 / R A T 1$ was made by ligating an internal HindIII 706-bp fragment into the HindIII site of pATH11 (20). The resulting plasmid coded for a fusion protein consisting of amino acids 168 to 403 from p116 fused to the first 324 amino acids of the trpE protein, creating a hybrid protein of approximately $66 \mathrm{kDa}$. Rabbit polyclonal antibodies were generated to the gel-purified trpE fusion protein. For immunofluorescence and Western immunoblot applications, crude sera were then immunopurified as fol- lows: fusion protein was obtained from $E$. coli extracts, electrophoresed by preparative sodium dodecyl sulfate (SDS)-polyacrylamide gel electrophoresis, and transferred to nitrocellulose. The nitrocellulose was stained by Ponceau $S$ to visualize protein, and the strip containing the fusion protein was excised. Crude antisera to p116 were incubated with the strip following standard Western blot procedures. The bound antibodies were eluted from the nitrocellulose by treatment with $0.2 \mathrm{M}$ glycine-1 mM EGTA [ethylene glycolbis( $\beta$-aminoethyl ether)- $N, N, N^{\prime}, N^{\prime}$-tetraacetic acid] (pH 2.7) and neutralized with $3 \mathrm{~N} \mathrm{NaOH}$. Immunopurified antisera was tested by Western analysis for its immunoreactivity to p116.

Indirect immunofluorescence. Anti-trpE::p116 antibodies were used for immunofluorescence as described by Adams and Pringle (1). To visualize nuclear DNA, cells were stained with $0.5 \mu \mathrm{g}$ of 4,6-diamino-2-phenylindole (DAPI) per $\mathrm{ml}$. Treated cells were mounted on glass slides in $1 \mathrm{mg}$ of $p$-phenylenediamine per $\mathrm{ml}$ in $90 \%$ glycerol. Cells were examined and photographed by using fluorescence microscopy with a Nikon Optiphot Microscope fitted with UV, fluorescein isothiocyanate, and rhodamine filters and Nomarski (DIC) optics. Kodak T-Max 400 35-mm film was used for all photography. NOP1 antibody was a gift from John Aris (4).

Protein synthesis. Cells were grown overnight to log phase at $23^{\circ} \mathrm{C}$ in YPD. Cells were harvested, washed twice with water, resuspended to $10^{7}$ cells per $\mathrm{ml}$ in low-sulfate medium (LSM [see above]), and incubated for $30 \mathrm{~min}$ at $23^{\circ} \mathrm{C}$ prior to the zero-time labeling point. At time zero, cells were split and half of each culture was shifted to $37^{\circ} \mathrm{C}$. For each labeling point, $1 \mathrm{ml}$ of culture was removed and labeled for 5 min at $23^{\circ} \mathrm{C}$ with $5 \mu \mathrm{Ci}$ of $\mathrm{Na}_{2}{ }^{35} \mathrm{SO}_{4}$. Labeling was terminated by addition of $1 \mathrm{ml}$ of $5 \%$ trichloroacetic acid plus $1 \%$ Casamino Acids. Samples were collected and counted by using GFA glass filters.

Protein manipulations. Yeast whole cell extracts were prepared by glass bead lysis in radioimmunoprecipitation assay buffer $(150 \mathrm{mM} \mathrm{NaCl}, 1 \%$ Nonidet $\mathrm{P}-40,0.5 \%$ sodium deoxycholate, $0.1 \%$ SDS, $50 \mathrm{mM}$ Tris- $\mathrm{HCl}$ [pH 8.0]) plus protease inhibitors (13). Total and insoluble $E$. coli proteins were prepared by the method of Koerner et al. (20). Proteins from RNase-containing fractions were precipitated with trichloroacetic acid to $5 \%$. Proteins were separated electrophoretically on 7.5 or $10 \%$ gels by the method of Laemmli (23) and were transferred to nitrocellulose by using a BioRad semidry transfer apparatus (13). For immunoblotting of hydroxylapatite column fractions, nitrocellulose membranes were blocked for $1 \mathrm{~h}$ in $5 \%$ instant milk in TTBS $(20 \mathrm{mM}$ Tris [pH 7.5], $500 \mathrm{mM} \mathrm{NaCl}, 0.05 \%$ Tween 20) and washed in TTBS. Washed blots were incubated 1 to $2 \mathrm{~h}$ with the appropriately diluted antiserum. Blots were then washed again and reacted with an anti-rabbit secondary antiserum (horseradish peroxidase conjugated), and immunoreactive bands were detected by enhanced chemiluminescence with a kit from Amersham. Immunoblotting of heparin-agarose column fractions was carried out with crude p116 antisera as described by Larimer and Stevens (25) by using ${ }^{125} \mathrm{I}$-protein A (ICN).

Exoribonuclease analysis. Enzymatic assay of exoribonuclease activity with $\left[{ }^{3} \mathrm{H}\right]$ poly $(\mathrm{A})$ as a substrate was carried out as described previously $(36,41)$ and a unit of activity, previously defined (41), is the amount needed to release 5 nmol of $\left[{ }^{3} \mathrm{H}\right] A M P$ from $150 \mathrm{nmol}$ of $\left[{ }^{3} \mathrm{H}\right]$ poly(A) per $30 \mathrm{~min}$ at $37^{\circ} \mathrm{C}$. Hydroxylapatite column fractions were also assayed with the addition of $20 \mathrm{mM}$ EDTA to the reaction mixtures, 
and the values obtained were subtracted from the plus $\mathbf{M g}^{2+}$ values. The $\mathrm{Mg}^{2+}$-independent activity was less than $10 \%$ of the $\mathrm{Mg}^{2+}$-dependent activity in all cases. Cells were grown in 1 liter of minimal medium to an $A_{650}$ of 1.7 to 1.9 and harvested. Crude extracts were prepared from the yeast parental strain grown with or without the $2 \mu \mathrm{m}$ plasmid harboring HKE1 (pMKHKE1) by the procedure described in Fig. 1 of Larimer and Stevens (25). The parental strain and the $h k e 1^{t s}$ mutant were grown similarly. Extracts $(1 \mathrm{ml})$ were resolved by hydroxylapatite (Bio-Rad) chromatography (2.7-ml columns) exactly as previously described (25). A $40-\mathrm{ml}$ linear gradient $(50$ to $500 \mathrm{mM}$ potassium phosphate buffer [pH 7.6]) was used, 1-ml fractions were collected, 15 $\mu l$ of every other fraction was assayed, and the results were plotted graphically as units of activity versus fraction number (see Fig. 5). The heparin-agarose chromatography was carried out as described in the legend to Fig. 6.

\section{RESULTS}

Cloning and sequence analysis of the $H K E 1$ gene. A genetic screen to select temperature-sensitive $(t s)$ mutants that exhibited altered transport of mitochondrial protein precursors yielded several mutants falling into different complementation groups, that were somehow defective in mitochondrial translocation. These studies will be presented elsewhere. In the course of this study, however, we arrived at one mutant in which the temperature sensitivity phenotype segregated independently of the mitochondrial defect. We also cloned this temperature-sensitive gene and showed it was an essential gene whose preliminary sequence analysis provoked an interest in pursuing further characterization (see below and Discussion). In this report, we describe the molecular characterization of this gene and the biochemical analysis of its gene product.

To further characterize the temperature-sensitive mutant, the recessive $t s$ allele was genetically complemented and shown to be the allele responsible for the temperaturesensitive growth by integrative mapping (see Materials and Methods). The complementing fragment was sequenced and contained an open reading frame of 1,007 codons $(3,021 \mathrm{bp})$ encoding a protein of approximately $116 \mathrm{kDa}$ (calculated molecular weight, 116,773 ).

The oldest complete sequence within the data base that revealed a significant homology with our open reading frame was the sequence for the yeast gene $K E M 1$ (18). In at least four other independent studies, the $K E M 1$ gene was identified from different activities and named XRN1, SEP1, RAR5, and DST2 (for a summary, see reference 17). For the purposes of this report, we will refer to the gene as $X R N 1 /$ $K E M 1$, and the protein it encodes $(175 \mathrm{kDa})$ will be referred to as p175.

Because of the high homology of the complementing gene with $X R N 1 / K E M 1$ and the potential for related function, it was originally named $H K E 1$ because of its homology to the karyogamy enhancing gene, KEM1. (Alignment of the HKE1 amino acid sequence with that for $K E M 1$ revealed several regions of significant stretches of homology, including $37 \%$ identity over 414 amino acid residues [3; data not shown].) Concurrent with our studies, although not yet present in the data base, were the sequence and molecular characterization of another gene $(R A T 1)$, which we now know to be identical to $H K E 1$ (3). Since our sequence was the same, it is not presented here. In order to be consistent with the literature, we will use $H K E 1 / R A T 1$ when referring to the gene name and p116 when referring to the protein.

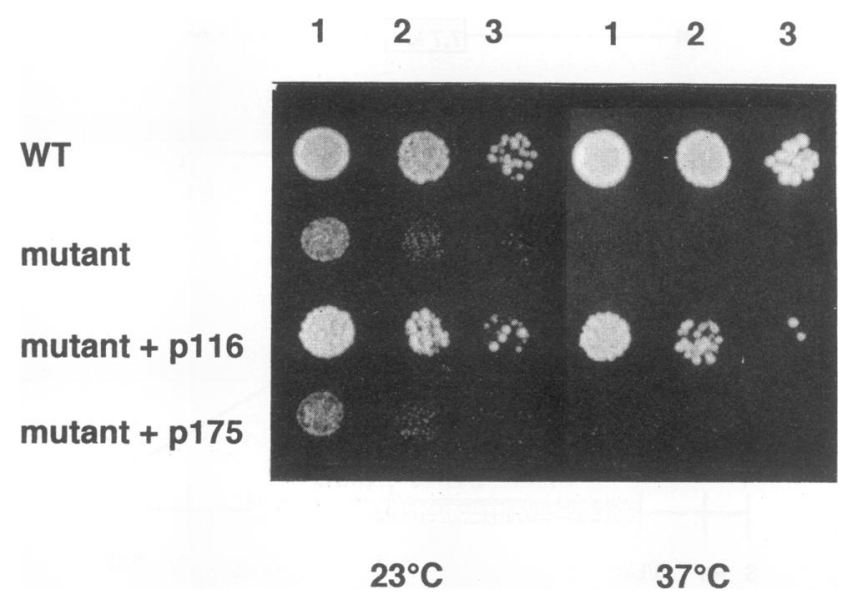

FIG. 2. XRN1/KEM1 fails to rescue the temperature sensitivity phenotype of hke1-1. hkel-1 is temperature sensitive for growth which is not reversed by the presence of the $X R N 1$ gene on a $2 \mu \mathrm{m}$ plasmid (YEp13XRN1). Shown are duplicate plates $\left(23\right.$ or $37^{\circ} \mathrm{C}$ ) of serial dilutions (columns: $1, \sim 10^{3}$ cells; $2, \sim 10^{2}$ cells; $3, \sim 10^{1}$ cells) of the wild-type (WT) or mutant strains indicated as mutant $\left(h k e 1^{t s}\right)$, mutant + p116 (hke ${ }^{t s}$ transformed with $H K E 1 / R A T 1$ on a $2 \mu \mathrm{m}$ plasmid, pMKHKE1), or mutant + p175 (XRN/KEM1 on a $2 \mu \mathrm{m}$ plasmid, pExo2).

HKE1/RAT1 is an essential gene that cannot be rescued by multicopy XRN1/KEM1. A URA3 gene flanked by his $G$ repeats (see Matérials and Methods) (Fig. 1) was inserted into $H K E 1$ and integrated into the genome to generate a heterozygous $H K E 1 / h k e 1:$ his $G$ diploid. The correct physical insertion of the integration was confirmed by Southern analysis (data not shown). Sporulation and tetrad analysis of this diploid revealed that spores harboring the hke1::hisG disruption were not viable. Microscopic examination of the disruptive spores revealed an early block in cell division. The spores either did not germinate or arrested growth after a single division. These data suggest an important role for the HKE1/RAT1 gene product in cell growth. A diploid strain bearing the disrupted gene and a wild-type copy of the gene on a URA3 plasmid was sporulated, and tetrads were dissected. Spores were allowed to germinate on rich medium and were later replicated to plates containing 5-FOA (5). All the cells that carry the his $G$ gene insertion (confirmed by PCR strategies) could not grow on 5-FOA, demonstrating that the disrupted strain requires the plasmid-borne copy of the gene for mitotic growth (data not shown). This result confirms that of Amberg et al. (3) for the disruption of $R A T 1$.

To confirm the independence of the cellular activities ascribed to the HKE1/RAT1 and homologous XRN1/KEM1 gene products, the hke1-1 mutant was transformed with $X R N 1 / K E M 1$ on a multicopy plasmid (pExo2) to determine if increased levels of p175 could rescue cells at the nonpermissive temperature. The transformed cells were compared with the hke1-1ts mutant cells rescued with the HKE1/RAT1 plasmid. As shown in Fig. 2, the thermosensitive growth of the hke1-1 ${ }^{\text {ts }}$ mutant was not rescued by $X R N 1 / K E M 1$ under conditions in which $H K E 1 / R A T 1$ rescued growth at $37^{\circ} \mathrm{C}$. Additionally, the $X R N 1 / K E M 1$ gene on a multicopy plasmid (pExo2) did not rescue the lethality of an hke1/rat1::URA3 disruption strain upon sporulation and tetrad analysis. The meiotic products from a disrupted diploid strain bearing $X R N 1 / K E M 1$ on a multicopy plasmid segregated as 2 viable:2 inviable spores (not shown). Parallel, control experi- 


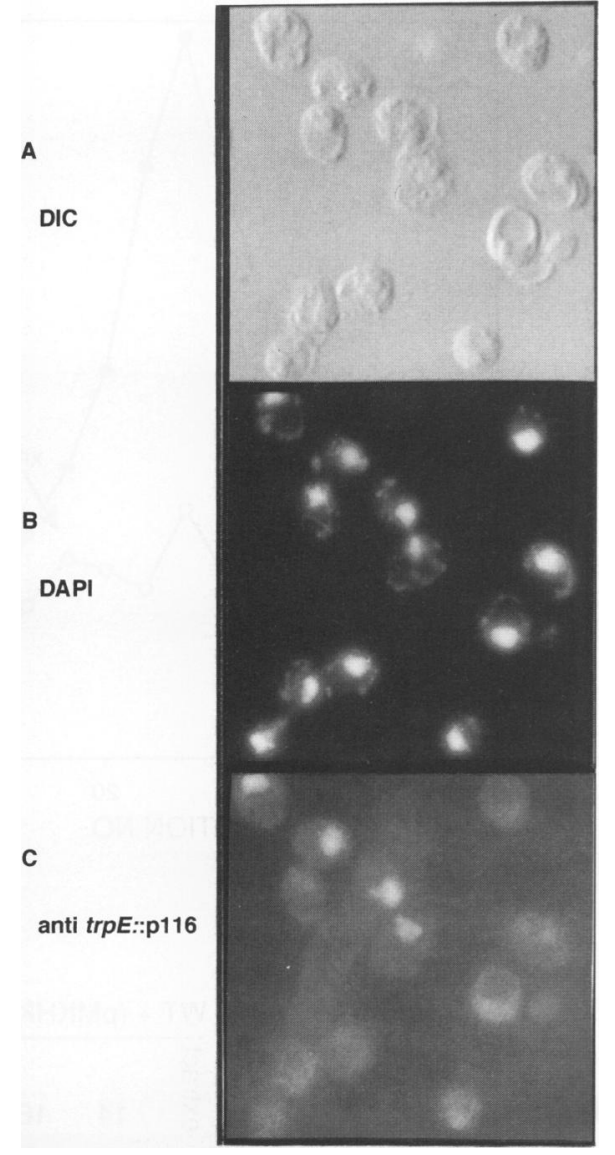

FIG. 3. Intracellular localization of p116. Polyclonal antibodies were generated to a trpE fusion protein made from amino acids 168 to 403 of p116. Crude sera were then immunopurified against the fusion protein obtained from $E$. coli extracts. Yeast cells bearing the hke1/rat1::URA3 disruption and HKE1/RAT1 on a high-copy-number vector (pMKHKE1) were fixed and prepared for immunofluorescence with trpE::p116 antibody as described in Materials and Methods. (A) Cell field as viewed by DIC optics; (B) the same cells stained with DAPI to visualize the nuclei; (C) fluorescence of the $\operatorname{trp} E:$ :p116 antibody, indicating a nuclear location for this protein in some of the cells.

ments were performed with pExo2 in the disruption mutant YPH500xrn1 to ensure that this plasmid can rescue the slow growth phenotype of an XRN1/KEM1 disruption mutant (25).

Antibody localization. Indirect immunofluorescence of wild-type yeast cells bearing $H K E 1 / R A T 1$ on a $2 \mu \mathrm{m}$ plasmid (pMKHKE1) using the anti-trpE::p116 antisera revealed a nuclear location for p116 in approximately 30 to $40 \%$ of the cells in a given field. The staining is distributed over the nucleus in the same space defined by DAPI detection of nuclear DNA (Fig. 3). Not shown is a control experiment using NOP1 antibodies. NOP1 is a nucleolar protein (4), and staining from this antibody was evident in the nuclei of all cells. This uniform nuclear staining by NOP1 indicates that the lower percentage of nuclear staining found with the anti-p116 antibodies was not likely due to artifactual effects from fixation or spheroplasting. It is possible that the nuclear localization in only some cells reflects a cell cycle-specific regulation of the localization of p116. However, because of the relatively low abundance of this protein in wild-type cells, antibody localization requires the expression of p116 from a multicopy plasmid. This may affect the normal subcellular localization of a protein.

Translation defect in $\boldsymbol{H K E} \mathbf{1}^{\text {ts }}$. In the study by Amberg et al. (3), RAT1 was identified from a screen designed to isolate temperature-sensitive mutants involved in the trafficking of mRNA from the nucleus. In situ localization of mRNA in this mutant reveals that it is not as efficiently released from the nucleus to the cytoplasm at the nonpermissive temperature. Mutant cells held at $37^{\circ} \mathrm{C}$ exhibit a marked nuclear staining of mRNA and loss of a cytoplasmic poly(A) signal compared with those of cells at $23^{\circ} \mathrm{C}$ or of the wild type at either temperature. In a similar study by Kadowaki et al. (16) a mutant (mtrl) that shows a similar mRNA nuclear retention phenotype is described. These authors additionally demonstrate that protein synthesis is decreased in this mutant while mRNA levels remain constant. To determine if the $h k e 1-1^{t s}$ mutant exhibited a similar phenotype, we examined protein synthesis in this mutant.

Wild-type and $h k e 1-1^{t s}$ cells were labeled with $\mathrm{Na}_{2}{ }^{35} \mathrm{SO}_{4}$ at the permissive and nonpermissive temperatures, and the abilities of the cells to incorporate amino acids were assayed (Materials and Methods). Protein synthesis in the hke1-1 temperature-sensitive mutant was significantly lower than that of wild-type cells following a shift to $37^{\circ} \mathrm{C}$. After shifting to the nonpermissive temperature, protein synthesis in the mutant begins to be reduced to levels less than $10 \%$ of that of wild type (Fig. 4B). The decrease in protein synthesis could reflect some posttranscriptional event that blocks the accessibility of RNA to the translation apparatus.

Evidence that the $H K E 1 / R A T 1$ gene encodes a protein with exonuclease (RNase) activity. The homologous p175 protein encoded by the $X R N 1 / K E M 1$ gene has been found to have $5^{\prime} \rightarrow 3^{\prime}$ exoribonuclease activity and $5^{\prime} \rightarrow 3^{\prime}$ DNase activity and to catalyze DNA strand exchange (for a review, see reference 17). It was first identified in studies of $5^{\prime} \rightarrow 3^{\prime}$ exoribonuclease activities in $S$. cerevisiae over 10 years ago $(36,41)$. Yeast exoribonuclease activities elute from hydroxylapatite columns in two discrete peaks (36) and are the predominant activities that hydrolyze poly(A) at $\mathrm{pH} 9.4$ and require $\mathrm{Mg}^{2+}$. These exoribonuclease activities account for $>80 \%$ of the $\mathrm{Mg}^{2+}$-dependent RNase activity of cytoplasmic and ribosome fractions of yeast cells (38). Earlier studies demonstrated that the exonuclease peak eluting from hydroxylapatite at higher salt concentrations was due to p175, the $X R N 1 / K E M 1$ gene product $(25,36)$. The first RNase peak, eluting at a lower salt concentration, has not been as extensively characterized, but it has been further purified (37) and found to degrade 5 ' terminally labeled rRNA and $\left[5^{\prime}{ }^{32} \mathrm{P}, 3 \mathrm{H}\right](\mathrm{pA})_{4}$ in the same manner as described for $\mathrm{p} 175$ $(36,38)$ (see Fig. 7). It is referred to as exo-2 below. To determine if the exoribonuclease activity of the lower-salt hydroxylapatite column peak was due in part to the highly conserved $H K E 1 / R A T 1$ gene product, we prepared protein extracts for hydroxylapatite column chromatography from a yeast strain harboring $H K E 1 / R A T 1$ on a multicopy plasmid and from the same strain without the plasmid. Quantitation of $\mathrm{Mg}^{2+}$-requiring poly(A)-hydrolyzing activities of fractions eluted from the hydroxylapatite columns revealed a four- to fivefold increase in the level of nuclease activity cofractionating with the peak eluting at lower salt concentrations in yeast cells bearing multiple copies of $H K E 1 / R A T 1$ (Fig. 5A). Because of the high level of this peak, p175 activity is found only as a shoulder of activity. The overproduced $H K E 1 /$ $R A T 1$ activity eluted in the same location as the peak of activity shown previously to remain in yeast cells harboring 


\section{A. GROWTH}

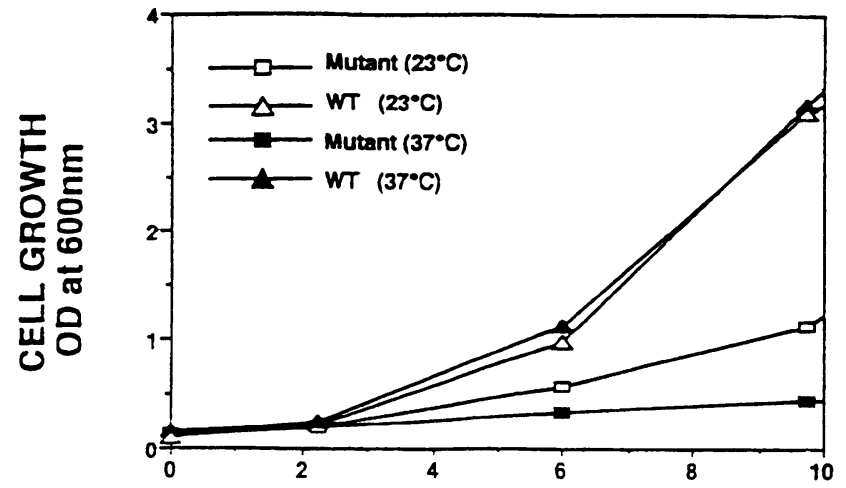

B. PROTEIN SYNTHESIS

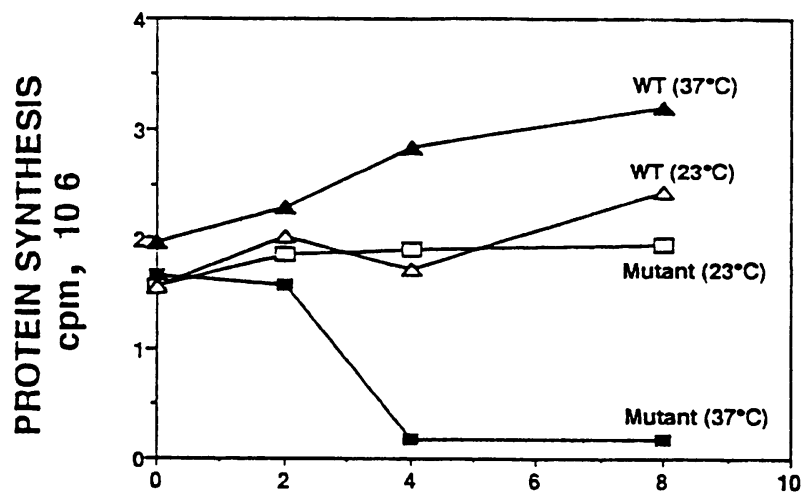

FIG. 4. Protein synthesis in hke1-1ts. (A) Log-phase cells grown at $23^{\circ} \mathrm{C}$ were shifted into fresh medium at the indicated temperatures. Aliquots were taken at the times indicated, and the optical density (OD) at $600 \mathrm{~nm}$ was determined. Open symbols represent cultures growing at $23^{\circ} \mathrm{C}$ and filled symbols represent cultures growing at $37^{\circ} \mathrm{C}$. (B) Protein synthesis was assayed by incorporation of $\mathrm{Na}_{2}{ }^{35} \mathrm{SO}_{4}$ as described in Materials and Methods. At the times indicated, aliquots containing the same numbers of cells were removed from the culture flask and labeled for $5 \mathrm{~min}$ by the addition of $5 \mu \mathrm{Ci}$ of $\mathrm{Na}_{2}{ }^{35} \mathrm{SO}_{4}$. Samples were treated as described and plotted as counts per minute versus time. Open symbols represent cultures growing at $23^{\circ} \mathrm{C}$ in LSM and filled symbols represent cultures growing at $37^{\circ} \mathrm{C}$ in LSM. WT, wild type.

a disruption of the p175-encoding gene (25). The increase in RNase activity is comparable to that observed for overproduction of p175 under identical conditions in earlier studies (25). The hke1-1ts mutant and parental strain were also grown at $23^{\circ} \mathrm{C}$, and extracts were examined in the same manner by hydroxylapatite chromatography. The extract of the parental strain showed results similar to those of Fig. 5A; however, the poly(A)-hydrolyzing peak eluting at lower salt concentrations was reduced to about $30 \%$ of the parental level in the $h k e 1^{t s}$ mutant (data not shown). The hke1-1 strain also grows more slowly, even at $23^{\circ} \mathrm{C}$ (Fig. 4A).

The increased level of RNase activity observed in Fig. 5A was consistent with an increased synthesis of the HKE1/ $R A T 1$ gene product from the multicopy $H K E 1 / R A T 1$ plasmid. However, the increase could also result from regulation of the synthesis or activity of the RNase by the HKE1/RAT1 gene. To eliminate this possibility, we used p116 antibody to show that it recognized a protein of the expected size of the $H K E 1 / R A T 1$ gene product $(116 \mathrm{kDa})$, that this protein was overexpressed by the $H K E 1 / R A T 1$ plasmid, and that it
A.
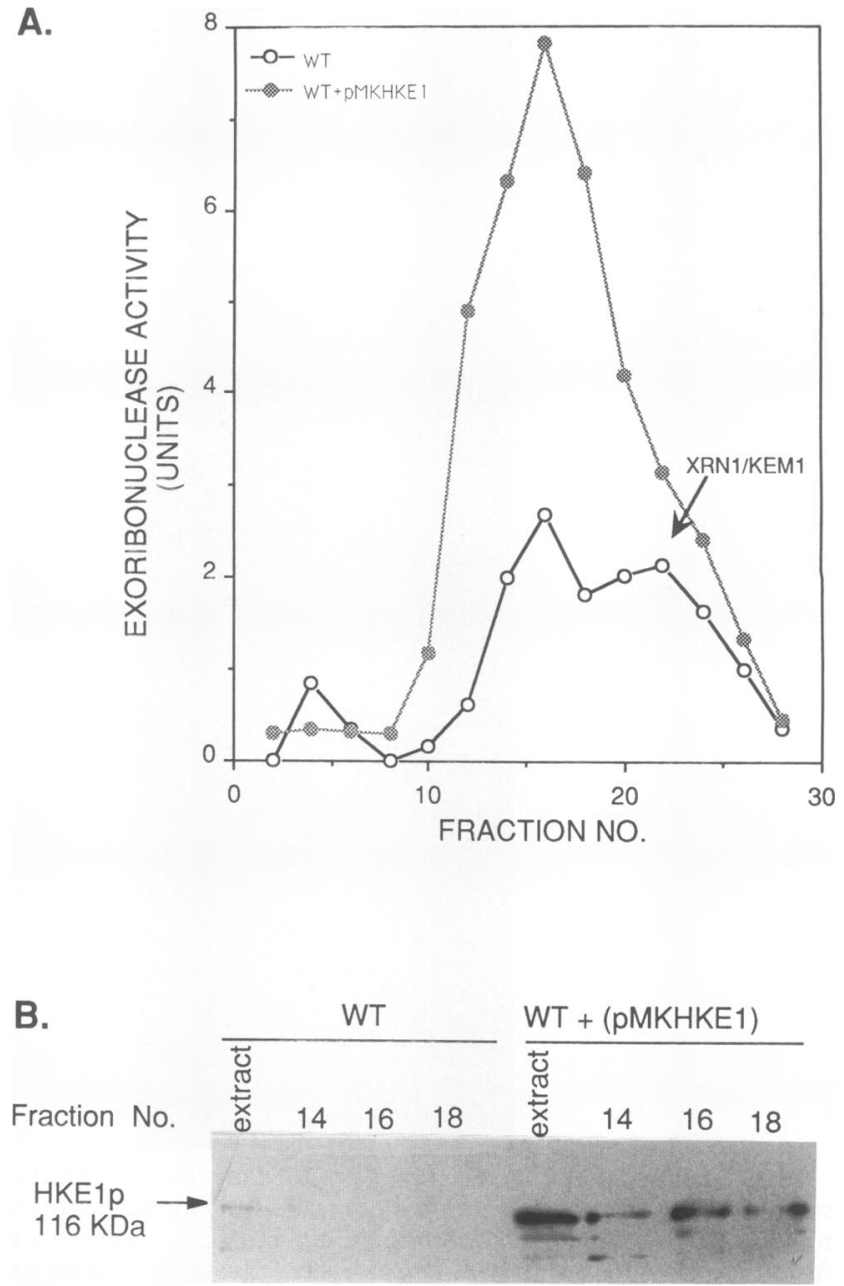

FIG. 5. (A) Separation of exoribonuclease activities from the p116 overproducing strain. Crude extracts were prepared from the yeast parental strain grown with or without pMKHKE1 $(2 \mu \mathrm{m})$ and chromatographed on a hydroxylapatite column, and fractions were assayed for exoribonuclease activity (see Materials and Methods). The values obtained were plotted as units of RNase activity versus fraction number. The peak of exoribonuclease activity at higher salt concentrations in fraction 24 of the wild-type extract is due to p175 (21). This peak of activity was only noted as a shoulder of the major low-salt peak in the HKE1/RAT1 overproducing strain. (B) Western blot of p116 in exonuclease-containing fractions. Immunopurified rabbit antibody to a TrpE::p116 fusion protein (see Materials and Methods) was used to probe a Western blot containing hydroxylapatite column fractions (Fig. 5A) with increased $5^{\prime} \rightarrow 3^{\prime}$ exoribonuclease activity as well as crude extracts. Lanes: extract, equal protein amounts of crude extracts from the wild-type parental strain (WT) or WT + pMKHKE1; 14, 16, and 18, equal loadings of total protein associated with the exoribonuclease peak (fractions 14, 16, and 18 , respectively) of WT or WT + pMKHKE1.

reacted with the RNase activity in these fractions. Immunoaffinity-purified antiserum to p116 was prepared (see Materials and Methods) and used to probe the crude extracts and the partially purified hydroxylapatite peak fractions (14, 16, and 18) of RNase activity found in Fig. 5A. These studies showed that a protein of approximately $116 \mathrm{kDa}$ was found in the fractions and recognized by the antiserum against p116 (Fig. 5B). The level of this protein was considerably increased (at least fivefold) in identical extracts from cells 
TABLE 1. Immunodepletion of RNase activity by anti-p116 antibodies ${ }^{a}$

\begin{tabular}{|c|c|}
\hline $\begin{array}{l}\text { Enzyme fraction } \\
\text { and serum }(\mu \mathrm{l})\end{array}$ & $\begin{array}{l}\% \text { Activity } \\
\text { remaining }\end{array}$ \\
\hline $\begin{array}{l}\text { None }(\text { WT) } \\
\text { Preimmune (1) } \\
\text { Preimmune (2.5) } \\
\text { Immune (1) } \\
\text { Immune }(2.5)\end{array}$ & $\begin{array}{r}100 \\
97 \\
95 \\
12 \\
10\end{array}$ \\
\hline $\begin{array}{l}16 \text { (WT + pMKHKE1) } \\
\text { None } \\
\text { Preimmune (1) } \\
\text { Preimmune (2.5) } \\
\text { Immune (1) } \\
\text { Immune (2.5) }\end{array}$ & $\begin{array}{r}100 \\
104 \\
107 \\
19 \\
10\end{array}$ \\
\hline 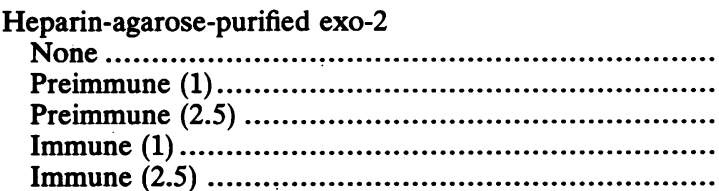 & $\begin{array}{r}100 \\
100 \\
93 \\
17 \\
7\end{array}$ \\
\hline
\end{tabular}

a Aliquots of the hydroxylapatite column fraction 16 of the wild-type extract $(3 \mu \mathrm{g})$ and the wild-type plus pMKHKE1 extract $(3.5 \mu \mathrm{g})$ (Fig. 5A, WT and WT + pMKHKE1, respectively) and $0.9 \mu \mathrm{g}$ of a heparin-agarose-purified exo-2 (36) were mixed with antiserum as shown above in reaction mixtures $(60$ ul) containing $16 \mathrm{mg}$ of albumin per $\mathrm{ml}, 1.6 \%$ Nonidet $\mathrm{P}-40,50 \mathrm{mM} \mathrm{NaCl}$, and $3.3 \mathrm{mM}$ sodium phosphate buffer (pH 7.2). After $4 \mathrm{~h}$ at $4^{\circ} \mathrm{C}$, protein A-agarose (Pierce) (30 $\mu \mathrm{l}$ of a $50 \%$ suspension) was added, and the suspensions were mixed for $2.5 \mathrm{~h}$ at $4^{\circ} \mathrm{C}$. Aliquots of the supernatant solutions following centrifugation were assayed as described in Materials and Methods, and the percent activity remaining in the supernatant is shown. The amount of crude rabbit antisera used is indicated.

harboring the multicopy plasmid pMKHKE1. The size of this protein correlated well with the estimated size $(116 \mathrm{kDa})$ from DNA sequence analysis of $H K E 1 / R A T 1$. The protein is barely detected in whole cell extracts at a protein level at which the overproduced protein is readily apparent [Fig. 5B, WT versus WT + (pMKHKE1)]. The activity increase measured (Fig. 5A) may represent a low estimate of the actual increase in vivo.

Immunodepletion of RNase activity was tested by the addition of the p116 antiserum to the peak hydroxylapatite fractions of Fig. 5A, as well as to a preparation of exo-2 purified from the YPH500xrn1 yeast strain as described by Stevens (37). Table 1 shows the results of the immunoprecipitation of RNase activity by the $\operatorname{trp} E:$ :p116 fusion protein antibody. Approximately $90 \%$ of the RNase activity was depleted from all the RNase-containing fractions upon incubation with the immune antiserum but not upon incubation with the preimmune serum.

Further purification by heparin-agarose column chromatography and Western immunoblot analysis of the overexpressed (HKE1/RAT1 plasmid-dependent) RNase activity was done so that a coincidental purification of the activity with that of the previously described exo- $2(36,37)$ could be demonstrated. These data are presented in Fig. 6. The overexpressed poly(A)-hydrolyzing activity of the hydroxylapatite column fractions obtained by chromatography of crude extracts (Fig. 5A) purifies similarly on a heparinagarose column to the exo-2 activity purified from a high-salt ribosome wash from yeast cells containing a disruption of XRN1 (37). The heparin-agarose chromatography results in an 8- to 10-fold purification of the RNase activity. All the overexpressed activity eluted in the peak shown. Figure 6B shows a Western blot of the peak fractions of each column. A protein band of approximately $116 \mathrm{kDa}$ is immunoreactive in each case and its elution profile parallels that of the activity. Although a difference in specific activity, i.e., RNase activity per immunoreactive protein, between the overexpressed and exo-2 fractions (approximately 1.5- to 2-fold; compare overexpressed fraction 37 with exo- 2 fraction 32 [Fig. 6B]) is apparent, quantitation of the actual amounts of protein loaded and present in the bands (e.g., by staining) was not possible because of the very low levels of protein (less than $20 \mu \mathrm{g} / \mathrm{ml}$ in the case of the exo-2 fractions). It is possible that the overexpressed protein differs in a structural modification(s) affecting RNase activity or immunoreactivity.

The poly(A) hydrolytic activity from both columns was found to be $\mathrm{Mg}^{2+}$ dependent, with $98 \%$ of the product being 5 -AMP (data not shown). Most of the studies of the mode of hydrolysis by exo-2, purified in the same manner as described in the legend to Fig. 6, have been done with $\left[{ }^{3} \mathrm{H}\right]$ poly(A) as the substrate (38). These studies also showed that about $98 \%$ of the hydrolysis product is $5^{\prime}$-AMP, with the remaining $2 \%$ being short adenylate oligonucleotides ( 2 to 4 nucleotides long). These are probably derived from the termini of the chains, since exoribonucleases often fail to hydrolyze the chain completely (36). With $\left[5^{\prime}{ }^{32} \mathrm{P}\right.$, ${ }^{3} \mathrm{H}$ ]poly(A) as a substrate, the only ${ }^{32} \mathrm{P}$-labeled product is 5'-AMP. Poly(A) lacking a 5'-phosphate end group is hydrolyzed by exo- 2 at $25 \%$ of the rate of poly $(\mathrm{A})$ containing a terminal phosphate. Similar findings have been found for p175 (41). The hydrolysis of RNA substrates has not yet been studied in detail, but Fig. 7 shows an analysis of the type of exoribonuclease activity of purified exo- 2 fractions, prepared in the same manner as those shown in Fig. 6, using yeast $\left[5^{\prime}-{ }^{32} \mathrm{P},{ }^{3} \mathrm{H}\right] \mathrm{rRNA}(25 \mathrm{~S})$ as a substrate at $0^{\circ} \mathrm{C}$. Label release upon incubation with the RNase was measured. The results show that the $5^{\prime}-{ }^{32} \mathrm{P}$ label is released considerably faster than the ${ }^{3} \mathrm{H}$ label, showing that a $5^{\prime} \rightarrow 3^{\prime}$ mode of hydrolysis is a predominant one. The enzyme fractions do not contain phosphatase activity since no conversion of $5^{\prime}$-AMP to adenosine or $\left[5^{\prime}-{ }^{32} \mathrm{P}\right] \mathrm{poly}(\mathrm{A})$ to ${ }^{32} \mathrm{P}_{\mathrm{i}}$ was found. Further analysis of the substrate and reaction specificity of exo- 2 is in progress.

\section{DISCUSSION}

In the present study we have characterized a conditional yeast mutant that is defective in the nucleolytic hydrolysis of RNA. The essential $H K E 1 / R A T 1$ gene uncovered by this mutation encodes a protein with significant homology to another yeast protein (p175) that exhibits a variety of biochemical activities, from strand exchange to exoribonuclease activity (17). In addition to the mRNA trafficking data previously published for $R A T 1$ (3), we show in the present ste $y$ that the $H K E 1 / R A T 1$ gene product exhibits a $5^{\prime} \rightarrow 3^{\prime}$ exoribonuclease activity like that previously demonstrated for the related $\mathrm{p} 175$.

p175 was purified to homogeneity based on its $5^{\prime} \rightarrow 3^{\prime}$ exoribonuclease activity $(36,41)$, and the gene encoding it was designated in subsequent studies as XRN1 (exoribonuclease $1[25])$. These earlier results on the analysis of poly(A) hydrolytic activity in cells lacking the active $X R N 1$ gene suggested that a second $5^{\prime} \rightarrow 3^{\prime}$ exoribonuclease which could partially compensate for the loss of p175 in $x r n 1$ disruption mutants existed (25). We have provided evidence that this 

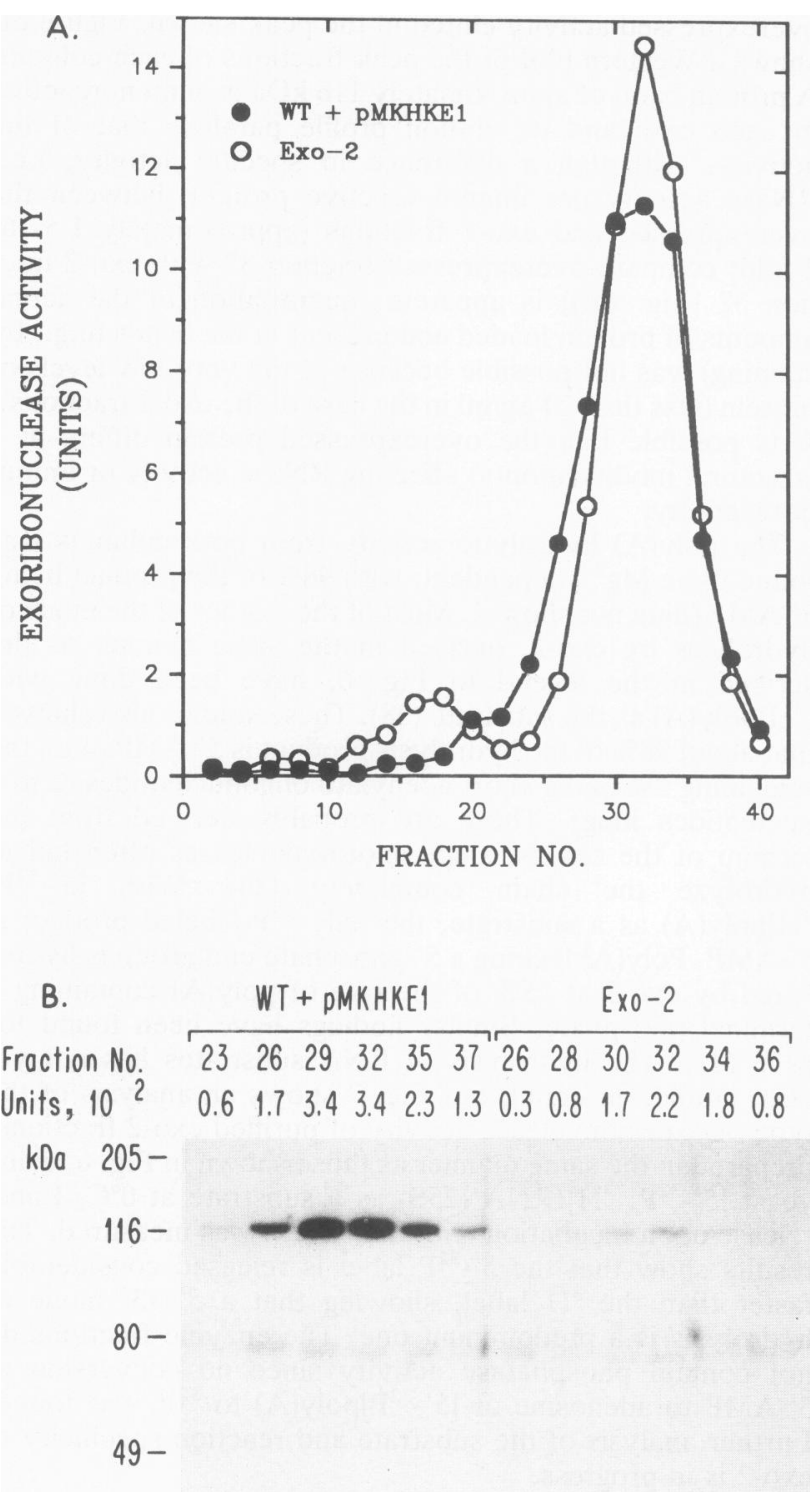

FIG. 6. (A) Heparin-agarose chromatography of the overexpressed RNase activity and exo-2. Hydroxylapatite chromatography of extracts of the yeast strain $(0.4 \mathrm{~g})$ containing the high-copynumber HKE1/RAT1 plasmid was carried out as described in Materials and Methods by using a 9-ml column and an 80-ml gradient of potassium phosphate buffer as described previously (36). Assay of fractions showed an elution profile similar to that of Fig. 5A. Fractions 13 to 17 , containing $4 \times 10^{3} \mathrm{U}$ of RNase activity, were combined, diluted with an equal volume of $20 \mathrm{mM}$ Tris- $\mathrm{HCl}$ buffer (pH 7.7)-10\% glycerol, and applied to a 4-ml column of heparinagarose (Sigma) prewashed with the same buffer containing $100 \mathrm{mM}$ $\left(\mathrm{NH}_{4}\right)_{2} \mathrm{SO}_{4}$. The column was then washed with $8 \mathrm{ml}$ of the same buffer and eluted with a $40-\mathrm{ml}$ linear gradient of 100 to $600 \mathrm{mM}$ $\left(\mathrm{NH}_{4}\right)_{2} \mathrm{SO}_{4}$. One-milliliter fractions were collected, and aliquots were assayed by using $\left[{ }^{3} \mathrm{H}\right]$ poly(A) as a substrate as described in Materials and Methods. Approximately $5.5 \times 10^{3} \mathrm{U}$ of RNase activity was recovered. For the exo-2 chromatography, exo-2 was purified as described by Stevens (37) from $5 \mathrm{~g}$ of the YPH500xml yeast strain through the hydroxylapatite chromatography step. Hydroxylapatite fractions (fractions 13 to 17) were combined, and $12 \times 10^{3} \mathrm{U}$ of RNase activity was chromatographed on heparinagarose as described above. Aliquots of the fractions were assayed, and $9.8 \times 10^{3} \mathrm{U}$ of activity was recovered. The elution profile, normalized to $50 \mathrm{U}$ of activity, is plotted for each column. (Both

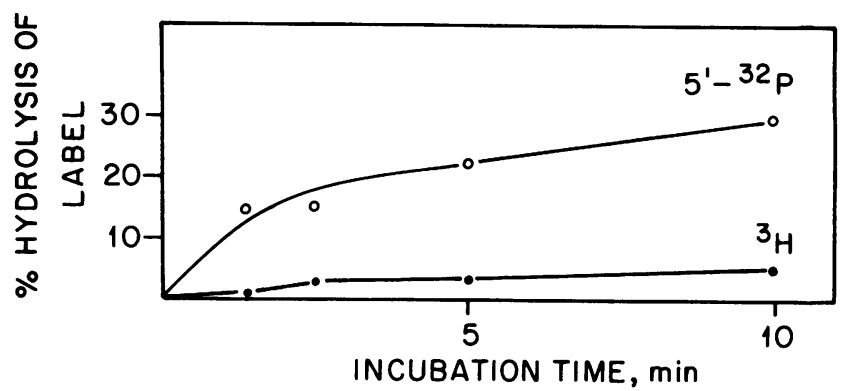

FIG. 7. Hydrolysis of $\left[5^{\prime}-{ }^{32} \mathrm{P},{ }^{3} \mathrm{H}\right] \mathrm{rRNA}$ by exo-2. $\left[5^{\prime}-{ }^{32} \mathrm{P},{ }^{3} \mathrm{H}\right]$ rRNA (25S) was prepared as described by Stevens and Maupin (40). The RNA $(1.3 \mathrm{nmol})$ was incubated for the times shown at $0^{\circ} \mathrm{C}$ with $50 \mathrm{U}$ of exo-2 (purified as described elsewhere [37]) in reaction mixtures $(50 \mu \mathrm{l})$ containing Tris-HCl buffer $(\mathrm{pH} 8.0)(25 \mathrm{mM})$, $\mathrm{NH}_{4} \mathrm{Cl}(50 \mathrm{mM}), \mathrm{MgCl}_{2}(3 \mathrm{mM})$, dithiothreitol $(0.5 \mathrm{mM})$, and $30 \mu \mathrm{g}$ of albumin. Assay of acid-soluble radioactivity was done as previously described (41). Control values for reaction mixtures lacking enzyme were subtracted.

second enzyme is encoded by the essential gene HKE1/ RAT1.

The gene for $\mathrm{p} 175$ was also cloned and sequenced in four other laboratories. By using an assay that detects the transfer of one strand of a DNA molecule to a complementary single-stranded partner (21), a gene for a strand-exchange protein, designated $S E P 1$, was characterized (42) and was independently confirmed by others and designated DST $2(9$, 10). $S E P 1$ was also shown to contain a $5^{\prime} \rightarrow 3^{\prime}$ exonuclease activity for the hydrolysis of both single- and doublestranded DNA (15). It is this latter activity that is likely responsible for synapsis and the observed $5^{\prime} \rightarrow 3^{\prime}$ polarity of the strand-exchange reaction. However, the mechanistic details of this activity are not resolved at present (17). Kolodner et al. (21) have data suggesting that p175 plays an important role in meiotic recombination. Finally, two other studies utilizing in vivo mutant screens that report either the fidelity of nuclear fusion (18) or the mitotic stability of minichromosomes containing altered origins (19) have yielded the same gene, designated KEM1 and $R A R 5$, respectively.

What do these seemingly different activities have to do with one another? Certainly, the same exonuclease could be involved in a number of different hydrolytic reactions and each reaction could affect distinct processes. Loss of the exonuclease could result in a confusing array of phenotypes. Events in which $5^{\prime} \rightarrow 3^{\prime}$ exoribonucleases may be involved have been described previously (41) and are discussed again below. Recent studies with p175 mutants show that mRNA turnover may be affected, resulting in differences in cellular mRNA and protein levels (24). Vreken and Raué also have recently presented results suggesting the involvement of such an exonuclease in mRNA turnover (43). A role for an exonuclease in such a process could affect many other activities in the cell.

protein and RNase activity elute from the current heparin-agarose columns at a higher salt concentration than previously described [37], apparently because of a difference in the heparin-agarose.) (B) Western blotting was carried out as described in Materials and Methods, by using $500 \mu$ l of the designated overexpressed RNase fractions and 200 $\mu l$ of the exo- 2 fractions. The units of RNase activity that were contained in each fraction are shown. WT, wild type. 
HKE1/RAT1 exoribonuclease activity and related phenotypes. An array of phenotypes is also found with the conditional $H K E 1 / R A T 1$ gene mutants. In vivo labeling studies to characterize the consequences of conditional defects associated with the loss of $H K E 1 / R A T 1$ activity reveal a posttranscriptional block in RNA utilization. Translation of mRNA is severely reduced at the restrictive temperature. This result might be expected in light of the findings of Amberg et al. for RAT1 (3). In situ localization of mRNA in this mutant reveals that it is not as efficiently released from the nucleus to the cytoplasm at the nonpermissive temperature. Mutant cells held at $37^{\circ} \mathrm{C}$ exhibit a marked nuclear staining of mRNA and loss of a cytoplasmic poly(A) signal compared with that of cells at $23^{\circ} \mathrm{C}$ or that of wild-type cells at either temperature. This phenotype for defects in hke1/ rat 1 mutants could be due to the failure of nuclear mRNA to efficiently clear the transcriptional process or the nucleocytoplasmic translocation apparatus (for a review, see reference 28). HKE1/RAT1 was also cloned independently in two other laboratories $(12,33)$, where it was uncovered as a temperature-sensitive suppressor of a tRNA promoter mutation (12) and as a gene whose overexpression would restore wild-type growth to yeasts bearing an overproduced amount of a mutated form of the transcription factor TFIID (33). These data also suggest that p116 may be involved in transcriptional processes and that the observed transport defects may be secondary effects due to the lack of production of components essential to RNA processing and trafficking.

As far as transcriptional involvement of p116 is concerned, the spectrum of nuclease and strand-exchange activities of the related $X R N 1 / K E M 1$ protein might suggest a similar potential role for the $H K E 1 / R A T 1$ gene product in transcript displacement from its DNA template (for additional discussion, see reference 17). However, factors such as these would be associated with RNA polymerase II, and thus such a role for p116 seems unlikely, since p116 does not appear to be a very abundant protein (as revealed by Western analysis of protein levels and Northern [RNA] analysis of message levels) relative to polymerase II. Possible involvement of a $5^{\prime} \rightarrow 3^{\prime}$ exonuclease in transcription termination has been suggested by Connelly and Manley (6). If the exonuclease were not actually involved in the termination event, it could affect the transcription processing pathway of mRNA by removing the 3 '-terminal fragments resulting from transcript cleavage for polyadenylation.

Rather than a transcription related function, p116 could be involved in RNA processing events within the nucleus. Amberg et al. (3) have already reported a pre-rRNA processing defect for $R A T 1$. The 5.8S rRNA was found to suffer a processing and maturation defect, such that slightly longer forms of this rRNA were produced at the nonpermissive temperature. The exoribonuclease activity ascribed to p116 may be in part responsible for trimming the $5^{\prime}$ ends of the 5.8S rRNA molecules, as suggested by these authors. It was previously suggested that the enzymatic properties of p175 make it a good candidate for '5' trimming reactions in rRNA maturation $(25,41)$. Additionally, it was found that fragments of the internal transcribed spacer 1 of pre-rRNA accumulate in yeast cells lacking p175 (39). This suggests a role for the latter enzyme as a scavenger RNase in pre-rRNA processing. It is plausible that p116 is involved in rRNA processing, both as a trimming and as a scavenger RNase which is somehow coupled to translocation across the nuclear envelope. Further investigation is necessary to uncover the interplay between all these seemingly diverse activities and to begin to better understand the temporal and spatial order of events involved in nuclear cytoplasmic RNA trafficking and the relationship among transcription, processing events, and trafficking. Additional study of the reaction specificity of p116 is currently under way.

\section{ACKNOWLEDGMENTS}

We thank Eva Hoke for her excellent technical assistance. We also acknowledge Ben Hall and Terri Aldridge for providing unpublished sequence data for us to compare with $H K E 1$, Chuck Cole and David Amberg for sharing their unpublished data and sequence, and Mark Goebl (Indiana School of Medicine) for drawing our attention to the KEM1 homology.

This work was supported by grants from the National Institutes of Health (GM41758) and the Robert A. Welch Foundation (AQ-814) and by an American Heart Association established investigator award, to M.G.D. A.S. was supported by the Office of Health and Environmental Research, U.S. Department of Energy, under contract DE-AC05-84 OR 21400 with the Martin Marietta Energy Systems. Direct support to A.S. was from a grant from the Exploratory Studies Program, Oak Ridge National Laboratory. M.M. was supported by an NRSA from the National Institutes of Health.

\section{REFERENCES}

1. Adams, A. E. M., and J. R. Pringle. 1984. Relationship of actin and tubulin distribution to bud growth in wild-type and morphogenetic mutant Saccharomyces cerevisiae. J. Cell Biol. 98:934945.

2. Alani, E., L. Cao, and N. Kleckner. 1987. A method for gene disruption that allows repeated use of $U R A 3$ selection in the construction of multiply disrupted yeast strains. Genetics 116: 541-545.

3. Amberg, D. C., A. L. Goldstein, and C. N. Cole. 1992. Isolation and characterization of RAT1: an essential gene of Saccharomyces cerevisiae required for the efficient nucleocytoplasmic trafficking of mRNA. Genes Dev. 6:1173-1189.

4. Aris, J. P., and G. Blobel. 1988. Identification and characterization of a yeast nucleolar protein that is similar to a rat liver nucleolar protein. J. Cell Biol. 107:17-31.

5. Boeke, J. D., F. LaCroute, and G. R. Fink. 1984. A positive selection for mutants lacking orotidine-5'-phosphate decarboxylase activity in yeast: 5-fluoro-orotic acid resistance. Mol. Gen. Genet. 197:345-346.

6. Connelly, S., and J. L. Manely. 1988. A functional mRNA polyadenylation signal is required for transcription by RNA polymerase II. Genes Dev. 2:440-452.

7. Devereux, J., P. Haeberli, and O. Smithies. 1984. A comprehensive set of sequence analysis programs for the VAX. Nucleic Acids Res. 12:387-395.

8. Douglas, M., B. Geller, and S. Emr. 1984. Intracellular targeting and import of an F1 $\beta$-subunit- $\beta$-galactosidase hybrid protein into yeast mitochondria. Proc. Natl. Acad. Sci. USA 81:39833987.

9. Dykstra, C. C., R. K. Hamatake, and A. Sugino. 1990. DNA strand protein $\beta$ from yeast mitotic cells differs from strand transfer $\alpha$ from meiotic cells. J. Biol. Chem. 265:10968-10973.

10. Dykstra, C. C., K. Kitada, A. B. Clark, R. K. Hamatake, and A. Sugino. 1991. Cloning and characterization of DST2, the gene for DNA strand transfer $\beta$ from Saccharomyces cerevisiae. Mol. Cell. Biol. 11:2583-2592.

11. Emr, S., A. Vassarotti, J. Garrett, B. Geller, M. Takeda, and M. G. Douglas. 1986. The amino terminus of the $F_{1}$-ATPase $\beta$-subunit precursor functions as a mitochondrial import signal. J. Cell Biol. 102:523-533.

12. Hall, B. D. (University of Washington). 1991. Personal communication.

13. Harlow, E., and D. Lane. 1988. Antibodies: a laboratory manual, p. 453. Cold Spring Harbor Laboratories, Cold Spring Hàrbor, N.Y.

14. Ito, H., Y. Fukuda, K. Murata, and A. Kimura. 1983. Transformation of intact yeast cells treated with alkali cations. J. Bacteriol. 153:163-168. 
15. Johnson, A. W., and R. D. Kolodner. 1991. Strand exchange protein 1 from Saccharomyces cerevisiae. J. Biol. Chem. 266: 14046-14054.

16. Kadowaki, T., Y. Zhao, and A. Tartakoff. 1992. A conditional yeast mutant deficient in mRNA transport from nucleus to cytoplasm. Proc. Natl. Acad. Sci. USA 89:2312-2316.

17. Kearsey, S., and D. Kipling. 1991. Recombination and RNA processing: a common strand? Trends Cell Biol. 1:110-112.

18. Kim, J., P. O. Ljungdahl, and F. R. Fink. 1990. kem mutations affect nuclear fusion in Saccharomyces cerevisiae. Genetics 126:799-812.

19. Kipling, D., C. Tambini, and S. E. Kearsey. 1991. rar mutations which increase artificial chromosome stability in Saccharomyces cerevisiae identify transcription and recombination proteins. Nucleic Acids Res. 19:1385-1391.

20. Koerner, T. J., J. E. Hill, A. M. Myers, and A. Tzagoloff. 1990. High-expression vectors with multiple cloning sites for the construction of trpE fusion genes: pATH vectors. Methods Enzymol. 194:477-490.

21. Kolodner, R., E. Alani, A. Johnson, D. Norris, and D. Tishkoff. 1992. Homologous pairing proteins in Saccharomyces cerevisiae. J. Cell. Biochem. 16(Suppl. B): 12 .

22. Kolodner, R., D. H. Evans, and P. T. Morrison. 1987. Purification and characterization of an activity from Saccharomyces cerevisiae that catalyzes homologous pairing and strand exchange. Proc. Natl. Acad. Sci. USA 84:5560-5564.

23. Laemmli, U. K. 1970. Cleavage of structural proteins during the assembly of the head of bacteriophage T4. Nature (London) 227:680-685.

24. Larimer, F. W., C. L. Hsu, M. K. Maupin, and A. Stevens. 1992. Gene 120:51-57.

25. Larimer, F. W., and A. Stevens. 1990. Disruption of the gene $X R N 1$, coding for a $5^{\prime} \rightarrow 3^{\prime}$ exoribonuclease, restricts yeast cell growth. Gene 95:85-90.

26. Lustig, A., R. J. Lin, and J. Abelson. 1986. The yeast RNA gene products are essential for mRNA splicing in vitro. Cell 47:953963.

27. Maniatis, T., E. F. Fritsch, and J. Sambrook. 1982. Molecular cloning: a laboratory manual. Cold Spring Harbor Laboratory, Cold Spring Harbor, N.Y.

28. Maquat, L. 1991. Nuclear mRNA export. Curr. Opin. Cell Biol. 3:1004-1012.

29. Martinez-Arias, A. E., and M. J. Casadaban. 1983. Fusion of the
Saccharomyces cerevisiae LEU2 gene to an Escherichia coli ß-galactosidase gene. Mol. Cell. Biol. 3:580-586.

30. Miller, J. 1972. Experiments in molecular genetics, p. 352-355. Cold Spring Harbor Laboratory, Cold Spring Harbor, N.Y.

31. Orr-Weaver, T., J. Szostak, and R. Rothstein. 1981. Yeast transformation: a model for the study of recombination. Proc. Natl. Acad. Sci. USA 78:6364-6358.

32. Ruby, S., and J. Abelson. 1991. Pre-mRNA splicing in yeast. Trends Genet. 7:79-85.

33. Schmidt, M. (University of Pittsburgh). 1992. Personal communication.

34. Sherman, F., G. Fink, and C. Lawrence. 1974. Methods in yeast genetics: a laboratory manual. Cold Spring Harbor Laboratory, Cold Spring Harbor, N.Y.

35. Sikorski, R. S., and P. Heiter. 1989. A uniform set of multipurpose shuttle vectors and yeast host strains designed for efficient manipulation of DNA in $S$. cerevisiae. Genetics 122:19-27.

36. Stevens, A. 1980. Purification and characterization of a Saccharomyces cerevisiae exoribonuclease which yields 5 '-mononucleotides by a $5^{\prime} \rightarrow 3^{\prime}$ mode of hydrolysis. J. Biol. Chem. 255:3080 3085.

37. Stevens, A. 1988. mRNA-decapping enzyme from Saccharomyces cerevisiae: purification and unique specificity for long RNA chains. Mol. Cell. Biol. 8:2005-2010.

38. Stevens, A. Unpublished data.

39. Stevens, A., C. L. Hsu, K. Isham, and F. W. Larimer. 1991. Fragments of the internal transcribed spacer 1 of pre-rRNA accumulate in Saccharomyces cerevisiae lacking $5^{\prime} \rightarrow 3^{\prime}$ exoribonuclease 1. J. Bacteriol. 173:7024-7028.

40. Stevens, A., and M. K. Maupin. 1985. A 5' $\rightarrow 3^{\prime}$ exoribonuclease of human placental nuclei: purification and substrate specificity. Nucleic Acids Res. 15:695-708.

41. Stevens, A., and M. K. Maupin. 1987. A 5' $\rightarrow 3^{\prime}$ exoribonuclease of Saccharomyces cerevisiae: size and novel substrate specificity. Arch. Biochem. Biophys. 252:339-347.

42. Tishkoff, D. X., A. W. Johnson, and R. D. Kolodner. 1991. Molecular and genetic analysis of the gene encoding the Saccharomyces cerevisiae strand exchange protein SEP1. Mol. Cell. Biol. 11:2593-2608.

43. Vreken, P., and H. A. Raué. 1992. The rate limiting step in yeast PGK1 mRNA degradation is an endonucleolytic cleavage in the 3 '-terminal part of the coding region. Mol. Cell. Biol. 12:29862996. 